\section{BLOOD CHIMERISM IN A PAIR OF TWINS}

\author{
BY
}

\section{P. B. BOOTH, M.R.C.S., L.R.C.P. GERTRUDE PLAUT, M.D.}

J. D. JAMES, M.R.C.S., L.R.C.P.

North London Blood Transfusion Centre, Edgware, Middlesex

ELIZABETH W. IKIN, B.Sc.

Medical Research Council Blood Group Reference

Laboratory, the Lister Institute, London

PHYLLIS MOORES, B.Sc.

RUTH SANGER, Ph.D.

AND

R. R. RACE, Ph.D., M.R.C.S., F.R.S.

Medical Research Council Blood Group Research Unit, the Lister Institute, London

This paper describes some tests on the blood of a brother and sister who are twins: the blood groups show that each twin is living on red cells only some of whose ancestors were directly inherited, the rest having been acquired as grafts in utero from the opposite twin; the presence of female "drumstick" nodules on the nuclei of some of the polymorphs of the male twin shows that ancestral white cells too must have been successfully grafted. Mixed blood in dizygotic twins is common in cattle but appears to be extremely rare in man.

In 1916 Lillie demonstrated an anastomosis of blood vessels between the chorions of dissimilar bovine twin embryos. Lillie said that the rapidly elongating embryos " meet and fuse in the small body of the uterus at some time between the $10 \mathrm{~mm}$. and $20 \mathrm{~mm}$. stage. The blood vessels from each side then anastomose in the connecting part of the chorion; a particularly wide arterial anastomosis develops, so that either foetus can be injected from the other." Lillie realized that in this anastomosis was to be found the explanation of the freemartin condition: hormones of the male twin, having crossed the anastomoses, could divert the proper development of the sex apparatus of the female twin. This explanation, so far as we know, has not been superseded.

In 1945 Owen discovered that the red cells of dizygotic twin cattle were antigenically a mixture of two kinds and that this could be explained if primordial red cells, having crossed the anastomoses, could take root and grow in the opposite twin. This discovery was of fundamental importance to the theory of the nature of antibodies (Burnet and Fenner, 1949).

In 1953 a blood donor, Mrs. McK., was found to have two kinds of blood (Dunsford, Bowley, Hutchison, Thompson, Sanger and Race, 1953). Of her red cells $60 \%$ were $\mathrm{O}, k k, J k^{a} J k^{b}$ and $40 \%$ were $\mathrm{A}_{1}, K k, J k^{b} J k^{b}$. On inquiry Mrs. McK. said she had had a twin brother who died in infancy 25 years before. As Mrs. McK.

Note.-In a letter to the British Medical Journal in $1953 \mathrm{Mr}$. S. Baron, of California, said that he himself must be a chimera "AO." in his R.A.F. days he had been told that he was group (B. W. I. and R.R.R.), and reference to our records showed him to be a normal group $\mathrm{B}$. We mention this in the hope that the lotter will no more be quoted as another example of a chimera. secreted $\mathbf{H}$ substance but no $A$ substance in her saliva it was assumed that the $O$ cells were her own and that the A cells were descendants of immigrant embryonic cells from her brother. Mrs. McK. is normal in every way and is clearly not a freemartin, for she has now had three children. Certain physical properties of the anti-B of Mrs. McK. showed it to be of the kind found in per. sons of the genotype $A_{1} O$, as opposed to the kind found in persons of the genotype $O O$ (Filitti-Wurmser and Jacquot-Armand, 1956).

Five months after the publication of this human example, mixed blood was reported in a pair of sheep twins (Stormont, Weir, and Lane, 1953); the twins were of different sex, and the female was found to be a freemartin.

In their masterly work "Quantitative Studies on Tissue Immunity," Billingham, Brent, and Medawar (1956) describe the finding that twin chicks are chimeras - probably all of them.

Another example of chimerism in man is reported by Nicholas, Jenkins, and Marsh (1957) in the present issue of this Journal.

Blood Groups of the Family W.

Recently Miss W., aged 21, made her first donation of blood at the North London Blood Transfusion Centre. Her red cells appeared at first to be a very weak form of group $A$, for when mixed with anti-A or anti-A+B on a slide and looked at through the microscope very small agglutinates were seen which were vastly outnumbered by unagglutinated cells : anti-B caused no agglutination. The serum of Miss W. contained anti-B but no anti-A. The very weak reaction with anti-A led to the testing of the blood of the W. family and the realization that we were dealing with another example of chimerism, this time with the advantage that both twins were alive.

The blood groups of the family of Miss W. are shown in the pedigree (see Fig.). Nothing unusual was found in the groups of her father or her mother or her elder brother. When the twin brother's blood was tested it was easily seen to be a mixture, because he has a much less unequal proportion of the two components than his sister. The two components of the mixed blood possessed by the twins differ in five systems: $\mathrm{ABO}, \mathrm{MNSs}, \mathrm{Rh}, \mathrm{Duffy}$, and Kidd. The grouping of the twin brother's blood is described first.

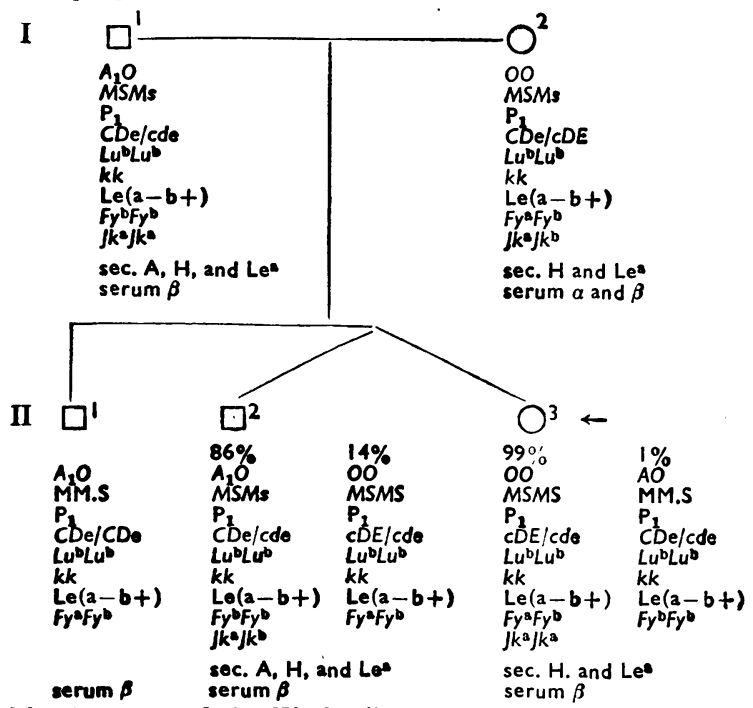

Blood groups of the $\mathbf{W}$. family. The groups directly under the twin chimeras, II-2 and II-3, are those of their inherited blood: a little to the right are those of their grafted blood. Antisera used : anti-A, $-A_{1},-B,-A+B,-H$; anti-M, -N, $-S$, -s, -U, -Mia, $-V w$; anti-P+ $P_{1}, P_{1}$; anti-C, - $,-C w,-D,-E,-e,-f,-V$; anti-Lua, -Lub; anti-K, -k; anti-Lea, -Leb; anti-Fya; anti-Jka, -Jkb. Arrow $=$ propositus. 
Method of Separating $O$ and $A_{1}$

The original method used by two of us (R. S. and R. R. R.) to separate the two components, $O$ and $A_{1}$, in the blood of Mrs. McK. was used again. The method is simple in principle. Anti-A is added to the mixed blood in a Petri dish. The larger agglutinates of $A$ cells are collected and are then freed from agglutinin by shaking in the presence of dissolved $A$ substance. The remaining mixture of $A$ and $O$ cells is put into a long tube and left to settle ; the agglutinated $A$ cells sink more quickly than the free $O$ cells, which are taken from the supernatant fluid.

As the method has not previously been published it may be useful to give some details here-though doubtless improvements could be made to every stage.

The amount of blood required depends on the proportions of the components. For II-2 three Petri dishes were enough, but for II-3 we used ten before we had a really adequate sample of A cells - for only about $1 \%$ of her cells were $\mathbf{A}$.

For the separations we used human anti-A and an extract of the seeds of Dolichos biflorus-which agglutinates $\mathbf{A}_{1}$ cells more avidly than does human anti-A (Bird, 1951). We are grateful to Lieutenant-Colonel G. W. G. Bird, who suggested the use of the extract because of its avidity and because, being a simpler substance than human anti-A, it might later be more easily won from the agglutinated A cells by the A substance. This proved indeed to be true.

Probably the more dilute the extract the better, so long as it can still cause enormous agglutinates of $A_{1}$ cells on a slide: a crude extract used diluted 1 in 5 was found to sensitize $A_{1}$ and $O$ cells for antiglobulin serum, so that subsequent tests had to be on saline suspensions of the separated cells. This difficulty was later overcome by using an extract that had been purified by chemical means : it could probably have been overcome by mere dilution of the extract.

1. Into each Petri dish put $2 \mathrm{ml}$. of diluted Dolichos biflorus extract (or $2 \mathrm{ml}$. of human anti-A diluted 1 in 2) and $0.5 \mathrm{ml}$. of a $50 \%$ suspension of the $A_{1}: O$ mixture of cells. Rock until the agglutinates do not seem to be getting bigger. (If the $A$ cells are relatively few the agglutinates are very small and difficult to catch; the agglutinates can be made larger by centrifuging the mixture and returning it to the dish.) Pipette the larger agglutinates into a tube marked $A$. Rock the dishes again and pipette their contents into a tube marked $\mathrm{O}$; the dishes are washed with a few millilitres of saline, which is transferred to tube 0 .

2. Fill tube $\mathbf{A}$ with saline and invert; when the agglutinates have settled (in a few seconds if they are large ones) remove the supernatant saline; wash in this way three more times. To the deposit of agglutinates add $3 \mathrm{ml}$. of A substance (Knickerbocker) and $3 \mathrm{ml}$. of saline. Shake hard and leave for about 20 minutes. Look for agglutinates in the supernatant suspension: if they are present add more A substance or perhaps wait longer. Fill the tube with saline, leave it to stand, first on a slope then vertically, for about an hour. Take as much as needed of the supernatant suspension, and wash the cells therein three times: this is the A sample.

3. While $\mathbf{2}$ is going on centrifuge tube $\mathbf{O}$ to bring small agglutinates together, but do not remove the supernatant antibody and saline. Add more saline, if necessary, to fill the tube; invert. Stand, first on a slope then vertically, for about an hour. Remove sufficient supernatant suspension, and wash the cells therein three times: this is the $\mathbf{O}$ sample.

\section{Groups of the Twin Brother, II-2}

The addition of anti-A caused large agglutinates to appear, but even by the naked eye a pink background could be seen which the microscope showed to be due to very large numbers of unagglutinated cells.

Some of the results of testing the red cells of II-2, untreated and after separation of the $A$ and $O$ components, are shown in the Table. The groups of the two fractions are given in the pedigree.

Reactions of Certain Critical Antisera with the Red Cells of II-2 Before and After Separation of the Two Components

\begin{tabular}{|c|c|c|c|c|c|c|c|}
\hline \multirow{2}{*}{$\begin{array}{l}\text { Red Colls } \\
\text { of } \mathrm{I}-2\end{array}$} & \multicolumn{7}{|c|}{ Anti } \\
\hline & $-\mathbf{A}$ & $-\mathbf{A}_{\mathbf{1}}$ & $-\mathbf{B}$ & -8 & $-\mathrm{C}$ & $-\mathbf{E}$ & -Fya \\
\hline $\begin{array}{l}\text { Untreated } \\
\text { A separated } \\
\text { O " }\end{array}$ & $\begin{array}{l}+++* \\
+ \pm+ \\
-\end{array}$ & $\begin{array}{l}+++ \\
+++\end{array}$ & $\bar{z}$ & $\begin{array}{l}\mathbf{w} \\
\pm \\
+\end{array}$ & $\begin{array}{l}+++ \\
+++\end{array}$ & $\frac{t^{*}}{++}$ & $\frac{w^{*}}{++}$ \\
\hline
\end{tabular}

The asterisk means that unagglutinated cells wero very obvious.
Theoretically the separation could have been made with anti-C, with anti-E, with anti-s, with anti-Fya, or with anti$\mathrm{Jk}^{\mathrm{b}}$, but the relative weakness of these agglutinations and the scarcity of the antisera made the separation with anti-A the obvious choice.

We did, however, make one cross-check. The red cells of II-2 were separated with anti-E (lacking incomplete anti-D) made very avid by the addition of Löw's (1955) papain solution. The separation was successful, for the supernatant unagglutinated cells were $C D e / c d e$, and, as anticipated, they were group A. (They were strongly agglutinated by anti-A and practically no unagglutinated cells were to be seen-in marked contrast to the effect of anti-A on the untreated sample.) The E cells were separated by mixing the blood of II-2 with the same anti-E but without the papain solution. The collected agglutinates could be freed from antibody by simply shaking hard with cold saline. Tests showed these cells to be $c D E / c d e$, and, as expected, group $O$. (The cells could not be freed from anti-E when papain had been used.)

\section{Groups of the Twin Sister, II-3}

The addition of anti-A caused very small agglutinates to appear, but the vast majority of the red cells were group 0 . The A cells were evidently too few in number to cause any difficulty in grouping by the other antisera, all of which are less sensitive than anti-A. The testing of the $O$ cells was therefore straightforward, and, as expected, the groups were those of the $\mathrm{O}$ component in the blood of the twin brother. The separation of the A cells was rather laborious, but it was done by the method described above. The groups of both fractions are shown in the pedigree.

\section{Proportions in the Mixtures}

Counts of the proportion of the two kinds of red cells possessed by each twin were kindly made by $\mathrm{Dr}$. P. L. Mollison and Miss Marie Cutbush, of the Medical Research Council Blood Transfusion Research Unit. Several ingenious methods were used and the results were:

$$
\begin{array}{ccccc}
\text { Twin brother, II-2 } & \ldots & \text { A } 86 \% & \ldots & \text { O } 14 \% \\
\text { Twin sister, II-3 } & . & \text { A } 1 \% & \ldots & \text { O } 99 \% \\
\text { Genotypes of the Twins } &
\end{array}
$$

Both twins are secretors: the brother secretes in his saliva $A$ and $H$ (and Lea), the sister secretes $H$ (and Lea). This would seem to establish beyond doubt that the genetic groups of the boy twin are those of the $A$ series and of the girl twin those of the $O$ series. The saliva of the boy twin did not differ detectably from that of his father in the amount of $A$ and $H$ substance it contained.

\section{White Cells of the Twins}

Dr. W. M. Davidson has kindly examined films of the blood of the twins and of their parents. In the films of the male twin polymorphs were found with the "drumstick" nuclear knobs present normally only in females (Davidson and Smith, 1954). The proportion of cells with "drumsticks" was compatible with a mixture of male and female blood in the proportion shown by the blood groups.

\section{Discussion}

Ninety per cent. of dizygotic bovine twins are said to have mixed blood, but in man it must be a great rarity. Were it not so the Transfusion Services would have detected more ABO mixtures, for, in England, about $34 \%$ of dizygotic twin pairs differ in their reactions with anti-A or with anti-B. (This figure is extracted from Smith and Penrose, 1955, Appendix Table 2, which gives phenotypic sib-sib frequencies for the ABO system in England.) The Blood Group Research Unit has tested, without finding a mixture, samples of blood from 77 pairs of twins thought by skilled observers to be dizygotic: 68 of them differed in their ABO, MNS, or Rh groups, and the antisera of these three systems should have been able to detect mixtures, had they occurred, in one or the other twin. (Of the remaining nine pairs, seven differed on other systems.) 
It follows that anastomoses between dizygotic human twins either must be very rare or must develop at a time when the ancestral blood cells are losing their faculty to take root in a foreign bed, or when the host tissue is becoming less tolerant of immigrant cells. Professor J. D. Boyd thinks that anastomoses are rare but probably not as rare as the very infrequent recognition of chimeras would suggest. In monozygotic twins, on the other hand, mixed blood must be very common-though undemonstrable.

Judging by the $\mathrm{W}$. twins it seems that, in man, the proportion of the two kinds of blood in one twin is independent of the proportion in the other twin. This is not what happens in cattle, for according to Irwin (1955) each of a pair usually has the same mixture ; that is to say, if twin A has $60 \% \mathrm{~A}$ blood and $40 \% \mathrm{~B}$ blood then his fellow twin B will also have $60 \% \mathrm{~A}$ blood and $40 \% \mathrm{~B}$ blood.

Dr. Davidson's finding of female "drumsticks" in the nuclei of some of the polymorphs of the male twin shows that the ancestors of these cells too can be successfully grafted. The proportion of polymorphs with " drumsticks" was compatible with a graft of the extent shown by the red cells ; if this proves a general rule it may have useful implications in the study of the lineage of these cells.

The female twin is of the genotype $O O$, and $99 \%$ of her red cells are group $O$. Her serum contains anti-B but no anti-A. The absence of anti-A is presumably a manifestation of the phenomenon of acquired tolerance, studied particularly by Billingham, Brent, and Medawar (1953, 1956); the presence of A cells early in uterine life has presumably inhibited the production of anti-A.

In cattle and in fowls the tolerance to foreign blood cells acquired in foetal life can later be shown not to be limited to blood cells: the majority of dizygotic twin cattle are fully tolerant to grafts of each other's skin (Anderson, Billingham, Lampkin, and Medawar, 1951), and the same is true of chickens (Billingham et al., 1956). Professor Medawar and his colleagues think it probable that skin could be successfully grafted between Miss W. and her twin brother.

Both twins are secretors. They secrete the $\mathrm{ABH}$ antigens for which they have inherited genes: they do not secrete the antigens of their grafted red cells. From this we may assume that the $\mathrm{ABO}$ genes do their parallel work of manufacturing water-soluble $A, B$, and $H$ substance in cells other than those in which they are busy providing alcohol-soluble $A, B$, and $H$ substance for the red cells.

The first human chimera to be recognized, Mrs. McK, has demonstrated conclusively, by having three children, that the hormones of a human male foetus had no power to upset the normal sexual development of his female twin. In the parallel situation a cow is sterile. Evidently the human male is backward, compared with the bull, in developing his endocrines-which is perhaps not surprising considering the relative tempo of their two lives. In man we suppose that the embryonic female hormones have no effect on the development of the male twin-but on this point there is so far no evidence.

\section{Summary}

Two human blood chimeras are described-twins of different sex. The male twin has $86 \% A_{1}$ and $14 \% O$ red cells; he also has female "drumsticks" in some of his polymorphonuclear white cells. The female twin has $99 \% \mathrm{O}$ cells and $1 \% \mathrm{~A}$ cells.

The $\mathrm{A}_{1}$ cells are $M S M s, C D e / c d e, F y^{b} F y^{b}, J k^{a} J k^{b}$; the $\mathrm{O}$ cells are $M S M S, c D E / c d e, F y^{a} F y^{b}, J k^{a} J k^{a}$; in their other groups they do not differ. Secretion tests on saliva show that the $A_{1}$ series belongs genetically to the male twin and the $O$ series to the female.

We are grateful to the blood donor, Miss W., and to her family. who have been most generous in their help. We are indebted to Dr. Amos Cahan, of the Knickerbocker Foundation, New York, for a large supply of A substance.

\section{REFERENCES}

Anderson, D., Billingham, R. B., Lampkin, G. H., and Medawar, P. B. (1951). Heredity. 5, 379.

illingham, R. E. Brent, L. and Medawar, P. B. (1953). Nature (Lond.), 172, 603.

Bird G (1956). Phil. Trans., 239, 357

Burnet, F. M., and Fenner, F. (1949). The Production of Antibodies. Burnet, F. M., and Fenner, F. (1949)

Davidson, W. M., and Smith, D. R. (1954). British Medical Journal, 2, 6 Dunsford, I., Bowley, C. C., Hutchison, A. M., Thompson, J. S., Sanger, R., and Race, R. R. (1953). Ibid., 2, 81.
Row

Filitti-Wurmser, S., and Jacquot-Armand, Y. (1956). Rev. Hémat. 11, 58. Irwin, M. R. (1955). In Biological Specificity and Growth, edited by E. G. Butler, p. 68. Princeton Univ. Press, New Jersey.

Lillie, F. R. (1916). Science, 43, 611 .

Löw. B. (1955). Vox Sanguinis (old series), 5, 94.
Nicholas, J. W., Jenkins, W. J., and Marsh, W. L. (1957). British Medical Journal, 1, 1458.

Owen, R. D. (1945). Science, 102, 400.

Smith, S. M., and Penrose, L. S. (1955). Ann. hum. Genet., 19, 273.

Stormont, C., Weir, W. C., and Lane, L. L. (1953). Science, 118, 695.

\section{HUMAN BLOOD CHIMERAS}

A STUDY OF SURVIVING TWINS

BY

J. W. NICHOLAS, M.R.C.S., L.R.C.P., D.C.P. Pathology Laboratory, Essex County Hospital, Colchester

\section{W. J. JENKINS, M.D.}

AND

W. L. MARSH, F.I.M.L.T.

North-East Metropolitan Regional Blood Transfusion Centre, Brentwood, Essex

The term " chimera" (originally a fabulous fire-spouting monster, part lion, part goat, and part serpent) has been used in botany for many years to denote an individual plant in which there are two or more tissues differing in their genetic constitution, such as a graft hybrid. Its first application in mammalian physiology appears to be that of Anderson, Billingham, Lampkin, and Medawar (1951), who applied it to the condition in cattle mentioned below.

It has long been known (Owen, 1945) that communication between the circulations of binovular bovine twins can occur in utero, resulting in an interchange of erythroblasts with persistence throughout life of mixed blood groups. The only such human chimera hitherto reported has been that of Dunsford, Bowley, Hutchison, Thompson, Sanger, and Race (1953), in which, unfortunately, one twin died in infancy. We now present a study of twins both of whom are chimeras and whose relatives were available. Simultaneously with this, another pair of chimeras is being reported by Booth, Plaut, James, Ikin, Moores, Sanger, and Race (1957).

The propositus, Mrs. W., is a healthy married woman aged 29 who attended for antenatal blood grouping in July, 1956. She has now had three pregnancies resulting in healthy children. When her blood was tested with anti-A serum moderate-sized agglutinates were seen in a sea of free cells. Further investigation showed her blood cells to be of two distinct groups. Her twin brother, both parents, husband, and all her three children were studied. The brother, as was first shown by Dr. Dorothy Parkin, is also a chimera. Neither of the twins has ever had a blood transfusion.

\section{Methode}

The mixture of cells in each chimera was separated by differential agglutination, using anti- $A$ and group $O$ sera in parallel, and the proportion of free group $O$ cells determined by triplicate counts in a haemocytometer. Deposited group A cells were freed of the $\alpha$-agglutinin by elution at $56^{\circ} \mathrm{C}$., but then gave equivocal results with most antisera. 